\title{
Genetic damage in Mexican and South American sweet corn varieties due to the herbicides nicosulfuron and topramezone
}

\author{
M.S. Reynoso ${ }^{1}$, C.M. Alvarez ${ }^{1}$, L.L. De la $\mathrm{Cruz}^{2}$, A.R.A. Villalobos ${ }^{3}$,
} J.F.G. Landeros ${ }^{1}$ and J.J.G. Sánchez ${ }^{2}$

${ }^{1}$ Environmental Mutagenesis Laboratory, Department of Cellular and Molecular Biology

${ }^{2}$ Institute of Management and Use of Plant Genetic Resources, Department of Agricultural Production

${ }^{3}$ Molecular and functional Genetics and Ecosystems Laboratory of Biomarkers and Molecular Genetics, Department of Cellular and Molecular Biology, University Center for Biological and Agricultural Sciences, Guadalajara University, Guadalajara, Jalisco, México

Corresponding author: C.A. Moya

E-mail: calvarez@cucba.udg.mx

Genet. Mol. Res. 18 (2): gmr18159

Received September 26, 2018

Accepted May 13, 2019

Published May 21, 2019

DOI http://dx.doi.org/10.4238/gmr18159

ABSTRACT. In order to facilitate corn production, herbicides such as nicosulfuron and topramezone are commonly used. Though they offer great advantages, they can affect crop productivity and induce DNA damage. The genotoxic activity of nicosulfuron was evaluated at two concentrations $(40,000$ and $80,000 \mathrm{ppm})$ and topramezone at four concentrations (1480, 148, 14.8 and $1.48 \mathrm{ppm}$ ) respectively, in sweet corn and hybrid accessions from Mexico and South America using a comet assay system. Sweet corn apical meristematic cell nuclei were tested in 113 accessions from Mexico and South America and five commercial hybrids for nicosulfuron and nine accessions and a hybrid for topramezone. Both nicosulfuron concentrations induced significant genetic damage to sweet corn and normal hybrids. Topramezone showed significant genotoxic activity in both sweet corn and normal hybrids. Normal hybrid corn was subject to genetic damage caused by the herbicides, and all showed significant 
genetic damage compared to their corresponding untreated controls. Genotoxic activity of nicosulfuron and topramezone was evident; additionally, the comet assay study demonstrated that corn can be used as a biomonitor for genotoxicity assessment.

Key words: Zea mays; Nicosulfuron; Topramezone; Genetic damage; Genotoxicity; Comet assay

\section{INTRODUCTION}

Corn is an extremely important crop in Mexico; a total of 28 million tons of corn were produced in 2016 alone (SIAP-SAGARPA, 2016). Corn is used in the production of many products (Fernández et al., 2013; Yadar and Supriya, 2014). Fertilizers, pesticides and herbicides are used to increase crop production and quality (Bolognesi, 2003; Hernández et al., 2016). Though herbicides offer many advantages, some of them produce adverse effects and can be genotoxic, induce DNA damage and affect crop productivity (Aksakal, 2013; Valencia-Quintana et al., 2013). Nicosulfuron and topramezone are two herbicides widely used on corn crops to control weeds (Labrador et al., 2000; Nuraky et al., 2011; Peachey and Mallory-Smith 2011). In the USA, many sweet corn varieties are severely damaged by herbicides, such as nicosulfuron and topramezone, if applied after seedlings have emerged (Pataky et al., 2006). Liu et al., (2003) reported no mutagenicity due to nicosulfuron in Salmonella thyphimurium and in mice. Tifensulfuron is an herbicide chemically related to nicosulfuron that did not show mutagenicity in tests on Salmonella typhimurium, micronuclei and chromosomes (Wang et al., 2004). However, another herbicide chemically related to nicosulfuron, belonging to the sulfonylurea family, did show genotoxic activity in Drosophila melanogaster (Heres-Pulido et al., 2008). Logran, which is also related to nicosulfuron, induced a series of chromosomic aberrations in meristem cells in the tip cells of Hordeum vulgare and Triticum aestivum roots (Kaymak and Gokalp, 2006).

Regarding topramezone, there is little evidence of genotoxicity. However, fipronil, which is chemically close to topramezone, induced a significant increase in sister chromatid exchanges as well as in micronuclei in human lymphocytes (Celik et al., 2014). Other four pesticides of the pirazolone family (bixafen, tebufenpirad, fenpyroximate and tolfenpirad), which are also related to topramezone, have shown genotoxic activity on SH-SY5Y line cells (Graillot et al., 2012).

Concerning herbicide genotoxicity, there is a wide array of bioassays that detect genetic damage (Valencia-Quintana et al., 2013; Zúñiga, 2013; Alvarez-Moya et al., 2014). One of the most modern assays for DNA damage detection is the comet assay, which is highly sensitive and reproducible (Singh et al., 1988). This test detects DNA damage such as simple and double chain breakage, crossed covalent bonds between DNA/DNA, DNA/proteins or base deamination due to oxidative damage at apurinic and apirimidinic sites, which results in DNA breakage and sites under repair (Azqueta and Collins, 2013). The comet assay has been widely used for genotoxic activity evaluation of pesticides (Alvarez-Moya et al., 2014).

Due to toxic effects on corn crops induced by nicosulfuron and topramezone, as well as the lack of evidence related to genotoxic activity of these two herbicides, the variety of assay systems used and the lack of reports stating which chemical forms of such 
herbicides possess genotoxic activity, there is a need to evaluate genetic damage induced by these herbicides in sweet corn. In the absence of existing data, genotoxicity evaluation should be carried out in sweet corn plants from different Mexican and South American regions. We evaluated the genotoxic activity of several concentrations of nicosulfuron and topramezone in Mexican and South American sweet corn accessions (SCAMCN) with the alkaline comet assay.

\section{MATERIAL AND METHODS}

\section{Plant material}

One hundred and thirteen sweet corn accessions were studied for nicosulfuron sensitivity, including two varieties from Mexico, three varieties from South America and five commercial corn hybrids (P3060, A7573, Oso, Tornado, Dk-2010). For topramezone, nine accessions were used from sweet corn varieties including five from Mexico, four from South America and the hybrid A7573.

The corn seeds were obtained from the germplasm bank of the Phytogenic Resources Management and Usage Institute (IMAREFI) of the Center for Biological and Agricultural Sciences of the University of Guadalajara. The material was increased during the spring-summer cycle of 2012 using fraternal crossbreeding. The seeds of each of the lines were planted in polystyrene trays with 60 cavities of $5 \mathrm{~cm}$ by $5 \mathrm{~cm}$ obtained from Proveedora de Insumos Forestales under greenhouse conditions in 2014 until plants reached a six leaf vegetative stage.

\section{Herbicide exposure}

Plants at growth stage 6 were subjected to two different commercial nicosulfuron (2-[(4,6-dimethoxypyrimidin-2-ylcarbamoyl) sulfamoyl]-N, N-dimethylnicotinamide or 1(4,6-dimethoxypyrimidin-2-yl)-3-(3-dimethylcarbamoyl-2-pyridylsulfonyl)urea)

concentrations: 40,000 and 80,000 ppm. Nicosulfuron was obtained from Syngenta Agro in México City. Two subjects were used per concentration and two subjects were used as a negative control, per each accession, including hybrids. Topramezone [3-(4,5-dihydro- 1,2 oxazole-3-il)-4-mesil-o-tolyl] (5-hydroxy-1-methylpirazole-4-yl) methanone] was obtained from Basf and the concentrations were 1480, 148, 14.8 and 1.48 ppm. Five sweet corn variety accessions from Mexico (CHIHUAHUA-194 Dulcillo del Noroeste, SONORA-25 Dulcillo del Noroeste, SONORA-118 Dulcillo del Noroeste, JALISCO-304 Maíz Dulce and M06124 Maíz Dulce) and 4 from South America (ARZM01-114 Dulce (ARGENTINA), BOLI-576 Chulpi (BOLIVIA), BOLI-921 Chulpi (BOLIVIA), PERU-392 Chuspillu (PERU) (the most representative) were used (CONABIO, 2011). Six subjects were used per concentration and six were used as negative controls, besides the hybrid. After $24 \mathrm{~h}$ of exposure, plants were taken to the laboratory for obtaining nuclei.

\section{Isolation of nuclei}

Cell nuclei of plants exposed to nicosulfuron, topramezone, hybrids and negative controls were obtained from meristematic leaf tips. One $\mathrm{cm}$ leaf cuts were washed three 
times with distilled water; afterwards they were placed in cold mortars with 3 drops of Honda buffer $(0.44 \mathrm{M}$ sucrose, $2.5 \%$ ficoll 400 type, $5 \%$ dextran $\mathrm{T}-40,2.5 \mathrm{mM}$ Tris- $\mathrm{HCl}$, $10 \mathrm{mM} \mathrm{MgCl} 2,10 \mathrm{mM}$ mercaptoethanol and 2.5\% TritonX-100 pH 8.5). The nuclei were obtained by maceration of the tissue and immediate filtration through filter paper of 20-25 $\mu \mathrm{m}$ particle retention (Whatman 4).

Obtaining nuclei: The filtered liquid was placed in $15 \mathrm{~mL}$ conical tubes and then centrifuged twice at $3000 \mathrm{rpm}\left(4^{\circ} \mathrm{C}\right)$ for $3 \mathrm{~min}$. The supernatant was discarded. The pellet containing nuclei was re-suspended in $200 \mu \mathrm{L}$ of Honda buffer (Alvarez-Moya et al., 2001) and then refrigerated at $4{ }^{\circ} \mathrm{C}$ until further use.

\section{Comet assay}

The nuclei contained in the suspension were used in the alkaline comet assay as described by Koppen and Verschaeve (1996). Slides were covered with Normal Melting Point (NMP) agarose at 1\%; it was allowed to solidify and then it was removed from the slides to have a completely clean surface. Afterwards, $300 \mu \mathrm{L}$ of Low Melting Point (LMP) agarose at $0.6 \%$ were placed on the slides. Once it solidified, another agarose layer was added (10 $\mu \mathrm{L}$ of the suspension containing nuclei and $90 \mu \mathrm{L}$ of the $0.5 \%$ LMP agarose), finally, a third layer of $0.5 \%$ LMP agarose was added to cover the second layer.

Slides containing exposed plants nuclei as well as non exposed plant nuclei (negative control) were submerged in a lysis solution $\left(\mathrm{NaCl} 2.5 \mathrm{mM}, \mathrm{Na}_{2}\right.$ EDTA $10 \mathrm{mM}$, Tris-HCl 10 mM, lauroyl sarcosinate 1\%, Tritón X-100 1\% y DMSO 10\%, pH 10) for $24 \mathrm{~h}$ at $4^{\circ} \mathrm{C}$. After lysis, slides were placed on a horizontal electrophoresis system with alkaline $\mathrm{pH}$ buffer $\left(\mathrm{NaOH} 30 \mathrm{mM}, \mathrm{Na}_{2} \mathrm{EDTA} 1 \mathrm{mM}, \mathrm{pH} 13\right)$ for $45 \mathrm{~min}$ at $4^{\circ} \mathrm{C}$, to allow DNA unfolding. Electrophoresis was carried out on the same system for $8 \mathrm{~min}$ at $1.0 \mathrm{~V} / \mathrm{cm}$ with amperage of $\sim 300 \mathrm{~mA}$. Slides were then washed with distilled water for $1 \mathrm{~min}$. Then, they were dyed with $100 \mu \mathrm{L}$ of ethidium bromide $(20 \mu \mathrm{g} / \mathrm{mL})$ and washed again with distilled water, 3 times. A fluorescence microscope with an excitation filter of 515-560 nm was used for the quantification of comets. The tail length was measured with the Comet assay system II software. 50 cometized nuclei per trial were analyzed.

\section{Statistical analysis}

DNA migration data was subjected to a variance analysis (ANOVA) using the Statistical Analysis System (SAS 9.0). A Dunnett multiple comparison assay was used to evaluate the effect of the herbicide treatment and the negative controls. A confidence level of 0.05 was used.

\section{RESULTS}

Table 1a shows the genetic damage on SCAMCN of 113 accessions exposed to different concentrations of nicosulfuron. The first concentration produced an average migration of $6.64 \mu \mathrm{m}$ and the second concentration showed an average migration of 6.11 $\mu \mathrm{m}$. They both showed a significant genotoxic activity $(\mathrm{P}<0.01)$ compared to the negative control. However, there were no significant differences when comparing the genotoxic effect between both of the evaluated concentrations. 
Table 1. Average tail length and standard deviation of DNA in (a) Mexican and South American sweet corn accessions and (b) apical meristem nuclei of 5 normal corn hybrids exposed to two different concentrations of the herbicide nicosulfuron.

\begin{tabular}{llll}
\hline $\begin{array}{l}\text { (a) } \\
\text { Populations studied }\end{array}$ & $\begin{array}{l}\text { Migration average tail length }(\boldsymbol{\mu m}) \\
\text { Negative control }\end{array}$ & $\begin{array}{c}\text { Concentration } \mathbf{4 0 , 0 0 0} \mathbf{~ p p m} \\
\text { Concentration 80,000 } \mathbf{~ p p m}\end{array}$ \\
\hline 113 & $1.59 \pm 0.22$ & $6.64^{*} \pm 2.22$ & $6.11^{*} \pm 2.07$ \\
\hline (b) & & \\
Normal corn hybrids & & & $6.53^{*} \pm 0.86$ \\
\hline 5 & $1.78 \pm 0.16$ & $5.76^{*} \pm 0.33$ &
\end{tabular}

The genetic damage induced by two different concentrations of nicosulfuron on SCAMCN of 113 accessions of México and South America is presented in Figure 1. There was a significant increase $(\mathrm{P}<0.01)$ in the comet tail length in both groups compared to their corresponding negative controls. However, the comparison of comet tails between groups (except controls) did not show significant differences $(\mathrm{P}>0.05)$.

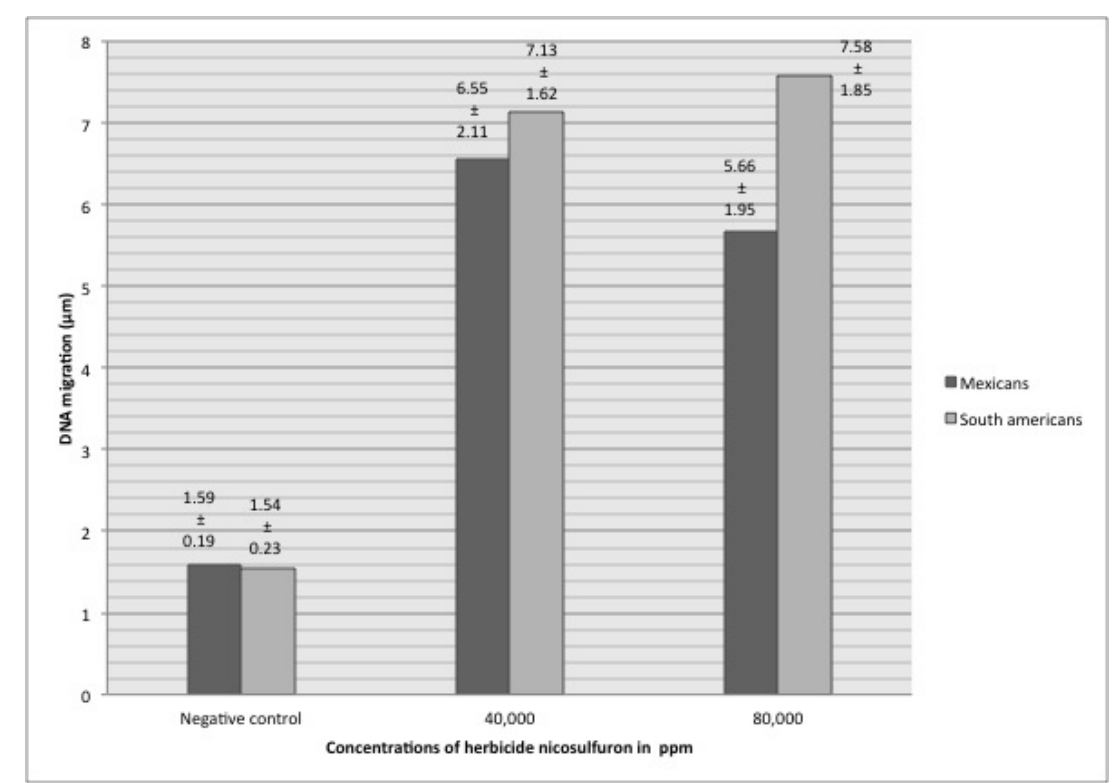

Figure 1. Average DNA migration from SCAMCN plants of 86 populations of Mexico and 27 of South America exposed to concentrations $(40,000$ and $80,000 \mathrm{ppm})$ of nicosulfuron.

Normal corn hybrids exposed to 40,000 and 80,000 ppm concentrations of nicosulfuron (Table $1 b)$ showed significant genetic damage $(\mathrm{P}<0.01)$ compared to controls. However, there were no significant differences when comparing the genotoxic effect between the evaluated concentrations.

Study by origin. SCAMCN of México and South America resulting from the exposure to two different nicosulfuron concentrations as well as the negative control are shown in Table 2. All of them showed significant genetic damage $(\mathrm{P}<0.01)$ in relation to their corresponding negative control. 
Table 2. Average tail length and standard deviation $(\mu \mathrm{m})$ in sweet corn varieties from México and South America (86 accessions from Mexico and 27 from South America) exposed to two different concentrations of nicosulfuron $(40,000$ and $80,000 \mathrm{ppm})$ plus negative controls.

\begin{tabular}{lrlcl}
\hline Origin & Populations & Negative control & Concentration 40,000 ppm & Concentration 80,000 ppm \\
\hline Chihuahua & 13 & $1.58 \pm 0.19$ & $6.75 \pm 1.50$ & $5.42 \pm 2.65$ \\
Durango & 3 & $1.45 \pm 0.14$ & $10.12 \pm 2.86$ & $6.37 \pm 1.63$ \\
Guanajuato & 6 & $1.32 \pm 0.12$ & $6.38 \pm 3.04$ & $3.33 \pm 1.19$ \\
Jalisco & 12 & $1.53 \pm 0.12$ & $5.77 \pm 2.20$ & $4.48 \pm 1.71$ \\
Michoacán & 14 & $1.69 \pm 0.21$ & $4.14 \pm 1.46$ & $4.63 \pm 0.94$ \\
Nayarit & 2 & $1.62 \pm 0.09$ & $7.02 \pm 0.09$ & $8.08 \pm 0.90$ \\
Sinaloa & 13 & $1.69 \pm 0.11$ & $7.58 \pm 1.54$ & $7.38 \pm 0.92$ \\
Sonora & 15 & $1.67 \pm 0.14$ & $7.44 \pm 1.09$ & $7.02 \pm 1.08$ \\
Zacatecas & 8 & $1.47 \pm 0.20$ & $6.85 \pm 1.27$ & $8.35 \pm 2.59$ \\
Argentina & 10 & $1.76 \pm 0.16$ & $7.82 \pm 2.08$ & $6.51 \pm 0.38$ \\
Bolivia & 3 & $1.26 \pm 0.07$ & $5.91 \pm 0.44$ & $7.52 \pm 0.41$ \\
Brazil & 2 & $1.43 \pm 0.13$ & $8.19 \pm 0.21$ & $7.22 \pm 1.88$ \\
Chile & 4 & $1.55 \pm 0.17$ & $6.50 \pm 1.33$ & $8.68 \pm 0.48$ \\
Ecuador & 6 & $1.42 \pm 0.10$ & $6.52 \pm 1.27$ & 0.37 \\
Perú & 2 & $1.35 \pm 0.27$ & $7.49 \pm 0.44$ & \\
\hline Migi & & &
\end{tabular}

Migration average of tail length is a result of the average of the averages of individuals studied. The differences in migration averages (Dunnett multiple comparison) between the experimental groups and the negative controls were significant $(\mathrm{P}<0.01)$.

Genetic damage is observed in SCAMCN for 5 Mexican and 4 South American accessions exposed to four different concentrations of topramezone (Figure 2). All concentrations showed significant genotoxic activity $(\mathrm{P}<0.05)$ compared to the negative control. However, multiple comparisons of migration averages of subjects exposed to different concentrations $(1480,148,14.8,1.48)$ did not show significant differences.

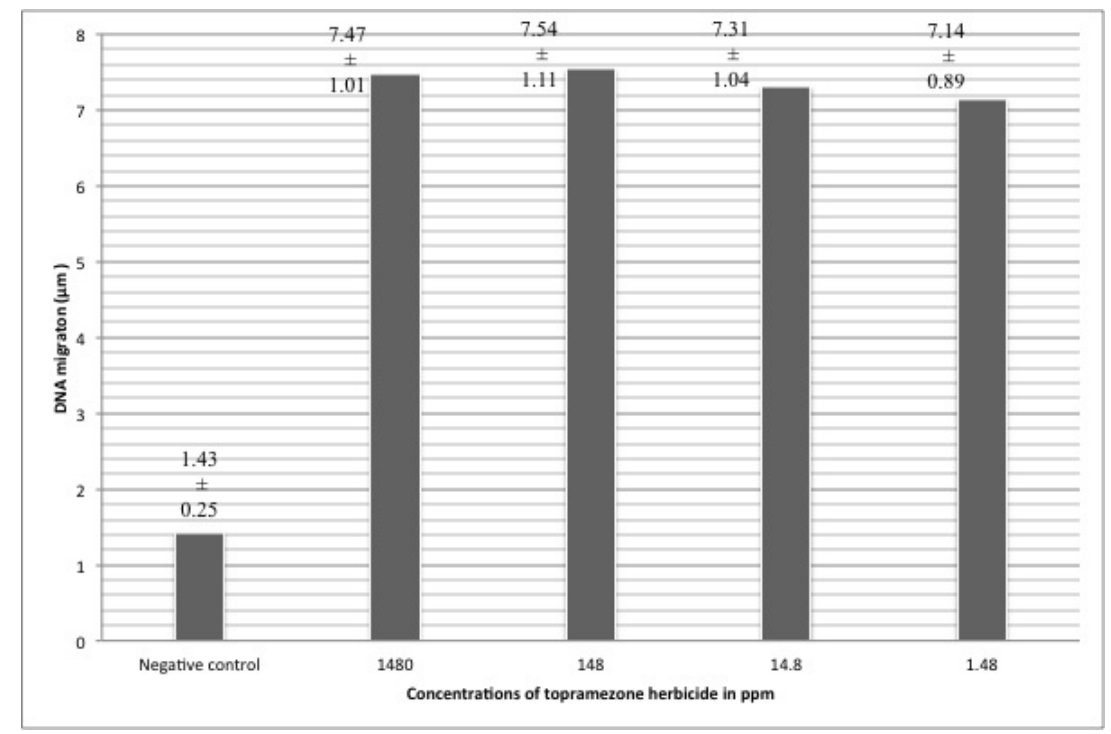

Figure 2. Average DNA migration from SCAMCN of plants Mexican and South American exposed to different concentrations (480, 148, 14.8, $1.48 \mathrm{ppm}$ ) topramezone herbicide. 
Significant genetic damage was observed in normal corn hybrids exposed to different topramezone concentrations (Figure 3) compared to the negative control $(\mathrm{P}<$ $0.01)$.

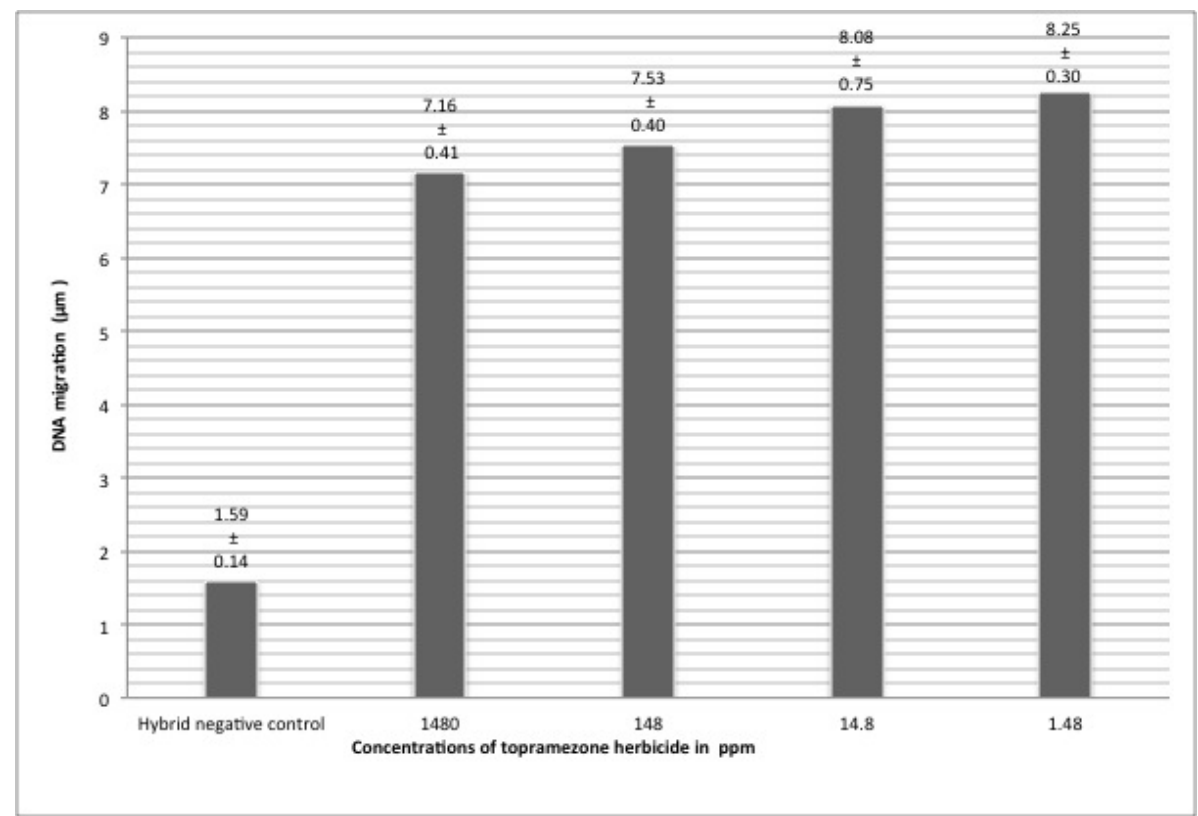

Figure 3. Average DNA migration from SCAMCN hybrid plants of normal maize exposed to different concentrations $(480,148,14.8,1.48 \mathrm{ppm})$ of the topramezone herbicide.

Study by origin. Significant genetic damage was observed in sweet corn varieties from México and South America compared to their negative controls $(\mathrm{P}<0.01)$ resulting from exposure to different topramezone concentrations (Table 3).

Table 3. Average tail length and standard deviation $(\mu \mathrm{m})$ in sweet corn varieties from México and South America (5 accessions from México and 5 accessions from South America) exposed to four different concentrations of topramezone $(1480,148,14.8$ and $1.48 \mathrm{ppm})$ plus negative controls.

\begin{tabular}{lclllll}
\hline Origin & Populations & $\begin{array}{l}\text { Negative } \\
\text { controls }\end{array}$ & $\begin{array}{l}\text { Concentration } \\
\mathbf{1 4 8 0} \mathbf{~ p p m}\end{array}$ & $\begin{array}{l}\text { Concentration } \\
\mathbf{1 4 8} \mathbf{~ p p m}\end{array}$ & $\begin{array}{l}\text { Concentration } \\
\mathbf{1 4 . 8} \mathbf{~ p p m}\end{array}$ & $\begin{array}{l}\text { Concentration } \\
\mathbf{1 . 4 8} \mathbf{~ p p m}\end{array}$ \\
\hline Chihuahua & 6 & $1.47 \pm 0.17$ & $7.42 \pm 1.00$ & $7.24 \pm 1.18$ & $6.81 \pm 0.65$ & $6.78 \pm 0.60$ \\
Jalisco & 6 & $1.28 \pm 0.10$ & $8.14 \pm 1.08$ & $7.06 \pm 0.47$ & $7.30 \pm 0.88$ & $6.50 \pm 0.48$ \\
Michoacán & 6 & $1.36 \pm 0.32$ & $6.85 \pm 0.84$ & $7.33 \pm 1.74$ & $7.61 \pm 0.82$ & $7.36 \pm 0.45$ \\
Sinaloa & 6 & $1.80 \pm 0.33$ & $7.46 \pm 0.52$ & $8.67 \pm 1.11$ & $7.58 \pm 0.62$ & $7.55 \pm 0.56$ \\
Sonora & 6 & $1.26 \pm 0.04$ & $7.52 \pm 0.79$ & $8.02 \pm 0.36$ & $8.44 \pm 1.17$ & $7.74 \pm 1.20$ \\
Argentina & 6 & $1.29 \pm 0.21$ & $7.97 \pm 0.54$ & $8.36 \pm 0.87$ & $6.68 \pm 0.53$ & $6.92 \pm 0.70$ \\
Bolivia & 6 & $1.33 \pm 0.15$ & $6.76 \pm 0.55$ & $6.63 \pm 0.78$ & $6.38 \pm 0.43$ & $6.26 \pm 0.57$ \\
Bolivia & 6 & $1.48 \pm 0.18$ & $8.04 \pm 1.24$ & $7.25 \pm 0.29$ & $7.09 \pm 0.47$ & $6.81 \pm 0.51$ \\
Perú & 6 & $1.41 \pm 0.16$ & $7.39 \pm 1.11$ & $7.09 \pm 0.93$ & $7.05 \pm 0.77$ & $7.18 \pm 0.50$ \\
\hline
\end{tabular}

Migration average of tail length is a result of the average of the averages of individuals studied. The comparison of migration averages (Dunnett multiple comparison) between the experimental groups and the negative controls were statistically significant $(\mathrm{P}<0.01)$. 


\section{DISCUSSION}

Nicosulfuron is used in diverse crops and frequently causes plant lesions or death (Robinson et al., 1994; O’Sullivan and Bouw, 1998; Ortiz et al., 2015). Previous reports barely mention acute damage comprising necrosis, chlorosis and plant death (Brown, 1990). On our study, Mexican and South American SCAMCN exposed to nicosulfuron presented significant genotoxic activity $(\mathrm{P}<0.01)$. The absence of significance when comparing the genotoxic effect among concentrations indicates that both produce the same amount of DNA damage (Table 1a). Previously, Heres-Pulido et al. (2008) and Kaymak and Gokalp (2006) showed the genotoxic effect of triasulfuron (chemically related to nicosulfuron) in Drosophila melanogaster and on meristematic cells of Hordeum vulgare and Triticum aestivum root tips, respectively. The aforementioned indicates that both nicosulfuron as well as some members of this chemical family have genotoxic activity.

Sweet corn crops are effectively damaged by nicosulfuron and foramsulfuron (Pataky et al., 2006; Ortiz et al., 2015) and sensitivity seems to be conditioned by one recessive gene of P450 cytochrome; however, according to previous reports on hybrid and endogamic sweet corn (Green and Ulrich, 1993; Williams et al., 2005; Pataky et al., 2006; Nordby et al., 2008; Pataky et al., 2008), this gene is associated to the dominant form (AA or Aa) (Pataky et al., 2008) and is unable to provide protection against the genetic damage reported here, which does not differ between sweet maize with different CYP genotypes. The damage does provide clues of the existing genetic risk. The significant increase $(\mathrm{P}<0.05)$ in comet tail length of Mexican and South American SCAMCN exposed to nicosulfuron (Figure 1) indicated that plants from both regions are genetically susceptible and the origin condition does not provide protection to genotoxic activity.

Hernández et al. (1996) and Arreaza (2000) reported that some normal corn hybrids (non sweet) presented morphologic and physiologic damage due to selective post-emerging herbicides. On our study, in accordance to what has been reported for sweet corn (Williams et al., 2005; Pataky et al., 2006; Nordby et al., 2008) independently from the used concentration, significant genetic damage $(\mathrm{P}<0.01$ ) was observed compared to negative controls (Table 2$)$.

The present study shows that the normal hybrid condition did not provide resistance to genetic damage caused by nicosulfuron. As it was observed, normal hybrids also showed genetic damage due to nicosulfuron. These results concord with the demonstrated by Meyer et al. (2010) that the genetic condition of corn hybrids is affected after the application of nicosulfuron in the growth stages of V3 to V5 or V5 to V5. It was observed that the origin of particular accessions (Table 3), does not provide protection to the genotoxic effect of nicosulfuron. There are no previous reports in this sense.

Topramezone is another of the herbicides used on corn crops. Soltani et al. (2007), Bollman et al. (2008) and Williams and Pataky (2010) reported tolerance to acute toxic effects (photobleaching) of topramezone on sweet corn hybrids, however the effect of the induced genetic damage was not evaluated. On our study with sweet corn, we observed high genetic sensitivity to topramezone in all concentrations (Figure 2). The aforementioned shows that topramezone is a powerful genotoxic even when there is tolerance on sweet corn hybrids. There is no evidence regarding topramezone genotoxic evaluation, however, four pesticides chemically related to the the pirazolone family have been studied (bixafen, tebufenpirad, fenpiroximat and tolfenpirad) on four cell lines and did show genotoxic activity on SH-SY5Y line cells (Graillot et al., 2012). Fipronil, another chemical related to topramezone, induced a significant increase of genetic damage on human lymphocytes (Celik et al., 2014). All topramezone concentrations showed a genotoxic effect compared to the negative control, regardless of their concentration 
(Figure 2). The above mentioned implies that even the lowest concentration (1.48 ppm) is capable of producing similar genetic damage to the highest concentration $(1480 \mathrm{ppm})$. Though there is a significant difference between these two concentrations (Figure 2), it is very likely that the genotoxic effect of the highest concentration is at such degree that DNA is almost destroyed and results in smaller comet tails similar to those produced by the lowest concentration. This atypical behavior has been reported previously when working with nitrosodiethylamide (Alvarez-Moya et al., 2001). The high genotoxic capacity of topramezone is extremely clear.

Regarding sweet corn hybrids, previous studies reported their tolerance to topramezone (Soltani et al., 2007; Bollman et al., 2008). In this study, normal hybrids (A7573) indicated that regardless of their tolerance there is a high degree of genetic damage induced by topramezone (Figure 3). Genotoxicity evaluation of topramezone regarding the origin condition of the corn (Table 3) showed significant genotoxicity $(\mathrm{P}<0.01)$ compared to their corresponding negative control on all of the studied accessions (Figure 2), as it was expected. It is evident that the origin condition did not provide protection from genetic damage induced by topramezone.

As previously reported, the comet assay is efficient for the evaluation of genotoxicity (Azqueta and Collins, 2013) and there are multiple organisms on which the comet assay is used as a biomonitor (Rucínska et al., 2004; Gichner et al., 2006; Olive and Banáth, 2006; Dhawan et al., 2009). Corn crops are continuously exposed to diverse herbicides and some of them are genotoxic (Rucínska et al., 2004; Gichner et al., 2006; Olive and Banáth, 2006; Dhawan et al., 2009). Therefore, having a biomonitor of genetic damage in corn crops is relevant. The comet assay in SCAMCN constitutes an important tool for the evaluation of genotoxic activity of commercial herbicides since it is fast and relatively cheap. Our study shows the benefits of using corn as a biomonitor of genetic damage induced by chemical substances (particularly herbicides). Both concentrations of nicosulfuron induced significant genotoxic activities on sweet corn and on normal hybrids. In the case of topramezone, significant genotoxic activity was shown for sweet corn and normal hybrids. None of the normal hybrids (not sweet) presented protection against the genotoxic effect of the studied herbicides. The genotoxic study indicated that both herbicides are genotoxic and that the comet assay in SCAMCN is an excellent tool for the evaluation of genotoxicity.

\section{ACKNOWLEDGMENTS}

Research partially supported by CONACYT 2012, México.

\section{CONFLICTS OF INTEREST}

The authors declare they have no conflict of interest.

\section{REFERENCES}

Alvarez-Moya C, Santerre-Lucas A, Zuñiga-Gonzalez G, Torres-Bugarin O, et al. (2001). Evaluation of genotoxic activity of maleic hydrazide, ethyl methane sulfonate and N-nitrosodiethylamine in Tradescantia. Salud Pública Méx. 43: 563-569.

Alvarez-Moya C, Silva MR, Ramírez CV, Gallardo DG, et al. (2014). Comparison of in vivo and in vitro genotoxicity of glyphosate isopropylamine salt in three different organisms. Gen. Mol. Biol. 37: 105-110.

Arreaza M (2000). Selectividad de nicosulfuron (4\% SC) en cuatro híbridos dobles de maíz amarillo (Zea mays L.). Rev. Fac. Agron. 26: 79-83.

Aksakal O (2013). Assessment of paraquat genotoxicity on barley (Hordeum vulgare L.) seedlings using molecular and biochemical parameters. Acta. Physiol. Plant. 35: 2281-2287. 
Azqueta A and Collins AR (2013). The essential comet assay: a comprehensive guide to measuring DNA damage and repair. Arch. Toxicol. 87: 949-968.

Bolognesi C (2003). Genotoxicity of pesticides: a review of human biomonitoring studies. Mutat. Res. 543: 251-271.

Bollman JD, Boerboom C, Becker R and Fritz V (2008). Efficacy and tolerance to HPPD-inhibiting herbicides in sweet corn. Weed Technol. 22: 666-674.

Brown M (1990). Mode of action, crop selectivity and soil relations of the sulfonylurea herbicides. Pest. Sci. 29: 263281.

Cavalcante D, Martinez C and Sofia S (2008). Genotoxic effects of Roundup sup /sup on the fish in Prochilodus lineatus. Genetic. Tox. Environ. Mutagen. 655: 41-46.

Celik A, Ekinci S, Güler G and Yildirim S (2014). In vitro genotoxicity of fipronil sister chromatid exchange, cytokinesis block micronucleus test and comet assay. DNA Cell. Biol. 33: 148-154.

CONABIO (2011). Comisión Nacional para el Conocimiento y Uso de la Biodiversidad. (www.conabio.gob.mx) consultado: Abril 2019.

Dhawan A, Bajpayee M and Parmar D (2009). Comet assay: a reliable tool for the assessment of DNA damage in different models. Cell. Biol. Toxicol. 25: 5-32.

Fernández S, Morales C and Mariscal A (2013). Importance of Mexican maize landraces in the national diet. An essential review. Rev. Fitotec. Mex. 3-A: 275-283.

Graillot V, Tomasetig F, Cravedi J and Audebert M (2012). Evidence of the in vitro genotoxicity of methyl-pyrazole pesticides in human cells. Genet. Toxicol. Environ. Mutagen. 748: 8-16.

Green JM and Uldrich JF (1993). Response of corn (Zea mays L.) inbreds and hybrids to sulfonylurea herbicides. Weed Sci. 41: 508-516.

Gichner T, Patkova Z, Szakova J and Demnerová K (2006). Toxicity and DNA damage in tobacco and potato plants growing on soil polluted with heavy metal. Ecotoxicol. Environ. Saf. 65: 420-426.

Heres-Pulido M, Lombera-Hernández S, Dueñas-García I, Perales-Canales I, et al. (2008). Genotoxicity of triasulfuron in the wing spot test of Drosophila melanogaster is modulated by winter wheat seedlings. Genet. Toxicol. Environ. Mutag. 653: 70-75.

Hernández L, Mejía A and Jose R (1996). Comparison of selectivity of nicosulfuron (4SC) alone and in mixture with six herbicides in two maize hybrids: Ceniap PB-8 (white) and Himeca 95 (yellow). In: VIII jornadas técnicas en biología y combate de malezas, Maracay Venezuela.

Hernández H, Méndez R, Beutelspacher A, Alvarez S, et al. (2016). Factores socioeconómicos y tecnológicos en el uso de agroquímicos en tres sistemas agrícolas en los altos de Chiapas, México. Interciencia. 41: 382-392.

KaymaK F and Gokalp FD (2006). The genotoxic effects of logran on Hordeum vulgare L. and Triticum aestivum L. Act. Biol. Hungar. 57: 71-80.

Koppen G and Verschaeve L (1996). The alkaline comet on plant cells: A new genotoxicity test for DNA breaks in Vicia faba roots cells. Mutat. Res. 360: 193-200.

Labrador M, Arreaza J and Lazo J (2000). Evaluación de nicosulfuron (4\% SC) en el control de malezas en maíz (Zea mays L.). Rev. Fac. Agron. 26: 79- 89.

Liu Y, Zhang Z and Shi Y (2003). The mutagenic study of nicosulfuron. J. Chin. Occup. Med. 2003: 10.

Meyer D, Pataky K and Williams M (2010). Genetic Factors Influencing Adverse Effects of Mesotrione and Nicosulfuron on Sweet Corn Yield. Agron. J. 102: 1138-1144.

Nordby N, Williams M, Pataky K, Riechers E, et al. (2008). A common genetic basis in sweet corn inbred Cr1 for cross sensitivity to multiple cytochrome P450 metabolized herbicides. Weed Sci. 56: 376-382.

Nuraky F, Lorzadeh S, Khodarahmpour Z and Rahmany H (2011). Weed integrated management (mechanical+ chemical) in maize (Zea mays L.) with post emergence herbicides. Adv. Environ. Biol. 5: 2063-2066.

Olive PL and Banáth JP (2006). The comet assay: a method to measure DNA damage in individual cells. Nat. Protoc. 1: 23-29.

Ortiz A, Torres S, Quintana Y and López A (2015). Primer reporte de Resistencia de Cyperus odoratus L. al herbicida pirazosulfuron-etilo. Bioagro. 27: 45-50.

O’Sullivan J and Bouw WJ (1998). Sensitivity of processing sweet corn (Zea mays L.) cultivars to nicosulfuron/rimisulfuron. Can. J. Plant. Sci. 78: 151-154.

Pataky K, Nordby N, Williams M and Riechers E (2006). Inheritance of cross-sensitivity in sweet corn to herbicides applied postemergence. J. Amer. Soc. Hort. Sci. 131: 744-751.

Pataky K, Meyer D, Bollman D, Boerboom M, et al. (2008). Genetic Basis for Varied Levels of Injury to Sweet Corn Hybrids from Three Cytochrome P450-metabolized Herbicides. J. Amer. Soc. Hort. Sci. 133: 438-447.

Peachey RE and Mallory-Smith C (2011). Effect of fall tillage and cover crop strategies on wild-proso millet (Panicum miliaceum) emergence and interference in snap beans. Weed Technol. 25: 119-126.

Robinson D, Monks D and Schultheis J (1994). Effect of nicosulfuron applied postemergence and post-directed on sweet corn (Zea mays L.) tolerance. Weed Technol. 8: 630-634.

Rucínska R, Sobkowiak R and Gwozdz E (2004). Genotoxicity of lead in lupin root cell as evaluated by the comet assay. Cell. Mol. Biol. Lett. 9: 519-528. 
SIAP-SAGARPA (2016). Resumen nacional por producto. (http://www.nube.siap.gob.mx/cierre_agricola/. Accessed January 23, 2018.

Singh N, McCoy M, Tice R and Schneider E (1988). A simple technique for quantitation of low levels of DNA damage in individual cells. Exp. Cell. Res. 175: 184-191.

Soltani N, Sikkema P, Zandstra J, O'Sullivan J, et al. (2007). Response of eight sweet corn (Zea mays L.) hybrids to topramezone. Hort. Sci. 42: 110-112.

Valencia-Quintana R, Sánchez J, Gómez-Arroyo S, Cortes J, et al. (2013). Genotóxicidad de los plaguicidas en sistemas vegetales. Rev. Intern. Contam. Amb. 29: 133-157.

Wang A, Feng X, Ye L, Wang W, et al. (2004). Studies on toxicity and mutagenicity of herbicide thifensulfuron. Chin. J. Indust. Med. 17: 13-15.

Williams M, Pataky K, Nordby N, Riechers E, et al. (2005). Cross-sensitivity in sweet corn to nicosulfuron and mesotrione applied postemergence. Hort. Sci. 40: 1802-1805.

Williams MM and Pataky KJ (2010). Factors affecting differential sensitivity of sweet corn to HPPD-inhibiting herbicides. Weed Sci. 58: 289-294.

Yadav V and Supriya P (2014). Maize: Nutrition Dynamics and Novel Uses. Springer, 141-152. (http://www.link.springer.com/chapter/10.1007/978-81-322-1623-0_12?no-access=true). Accessed January 1, 2018.

Zúñiga G (2013). Sistemas de detección de daño genético. In: Genética Ambiente y salud. $3^{a}$ ed. (Alvarez MC, ed.). Universidad de Guadalajara, Guadalajara, 99-119. 